\title{
History of Science
}

the only review of literature and research in the history of science, medicine and technology in its intellectual and social context

\section{2-1986}

\section{A special post-free offer to new subscribers valid until 31 December 1987}

\section{Volumes 1-24 hardbound, US \$545/£272.50}

From Science History Publications Ltd, Halfpenny Furze, Mill Lane, Chalfont St Giles, Bucks HP8 4NR, England

History of Science is published quarterly in issues of about 112 pages.

Volume 25 (1987) will include

A. I. SABRA Greek Science in Medieval Islam

Norton Wise and Crosbie Smith Work and Waste: Political Economy and Natural Philosophy in Nineteenth Century Britain

Albert Rothenberg Einstein, Bohr, and Creative Thinking in Science

Malcolm Nicolson Alexander von Humboldt, Humboldtian Science and the Origins of the Study of Vegetation

PNINA G. ABIR-Aм The Biotheoretical Gathering, Transdisciplinary Authority and Molecular Biology in the 1930s

L. S. JaCYNA Medical Science and Moral Science: Physiology in Restoration France

JAN GoLINSKI Metzger and Seventeenth Century Chemistry

J. R. R. CHRISTIE Narrative and Rhetoric in Metzger's Historiography

The Annual Subscription is US $\$ 85.00$ post-free in the Americas and Japan, $£ 42.50$ elsewhere $(\$ 42.00 / £ 20.50$ direct to private subscribers). Write to: Science History Publications Ltd, Halfpenny Furze, Mill Lane, Chalfont St Giles, Bucks HP8 4NR, England 


\section{"A bold and persuasive work, scrupulously researched and well argued."*}

\section{THE DECLINE OF THE OLD MEDICAL REGIME IN STUART LONDON By Harold J. Cook}

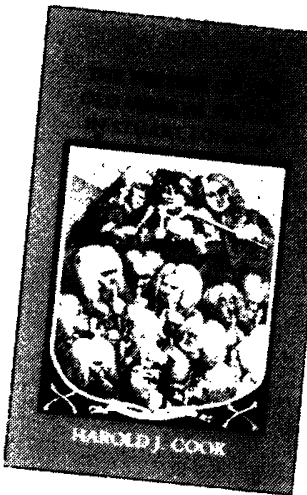

"The College of Physicians' attempt to control the medical practice in this period has been studied before, but Cook has provided the most accurate and persuasive account of the political changes that doomed its efforts."- "Michael MacDonald, Department of History, University of Wisconsin, Madison. 11 b\&w illustrations. $\$ 32.95$

\section{CORNELL UNIVERSITY PRESS} 26 Charing Cross Road, London WC2H OLN England

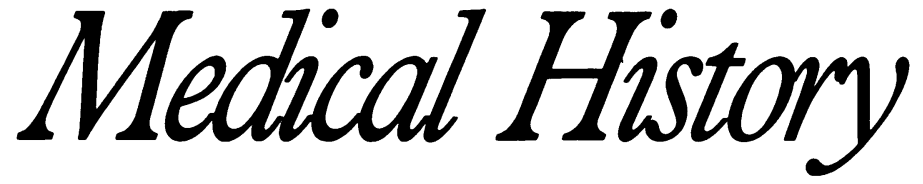

The following hardback supplements are available:

No. 1 (1981)-Theories of Fever from Antiquity to the Enlightenment, UK $£ 6 /$ overseas $£ 9$.

No. 2 (1982)-The Paradox of Rembrandt's 'Anatomy of Dr Tulp', UK $£ 9 /$ overseas $£ 13$.

No. 3 (1983)-A Study of the English Apothecary 1660-1760, UK £9/overseas $£ 13$.

No. 4 (1984)-Xavier Bichat and the Medical Theory of the Eighteenth Century, UK $£ 11 / o v e r s e a s ~ £ 15$.

No. 5 (1985)-The Emergence of Modern Cardiology, UK $£ 12$ /overseas $£ 16$.

No. 6 (1986)-The Library of Dr John Webster, UK $£ 14 /$ overseas $£ 18$. (In press.)

No. 7 (1987)-A Medical Student at St Thomas's Hospital, 1801-1802, UK £14/overseas $£ 18$. (In press.)

Orders to Professional \& Scientific Publications, BMA House, Tavistock Square, London WC1H 9JR, England. 


\section{MEDICAL BOOKS}

Prints * Portraits

Old, Rare,

\section{\& OUt-OF-Print}

America's Largest Stock

All items are fully catalogued and classified. American and European, dating from the 15th to the 20th centuries particularly classical and unusual works. with emphasis upon history, biography, and specialized medicine.

Lists issued in all fields of medicine.

We are eager to purchase small or large collections.

\section{ARGOSY BOOK STORES}

116 E. 59th St., N.Y., N.Y. 10022 , PL.3-4455
F. E.

Whitehart

40 Priestfield Rd.

Forest Hill

London SE23 2RS

01-699 3225
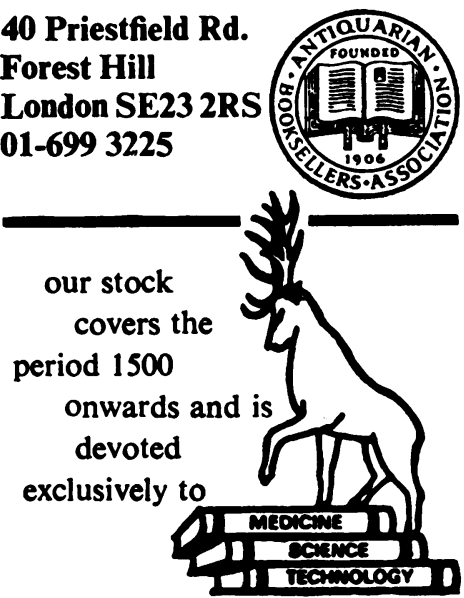

CATALOGUES ISSUED

Normal business hours or by appointment
Rare Books \& Manuscripts in the bistory of

Medicine \& the Sciences

BOUGHT $\cdot$ SOLD $\cdot$ APPRAISED

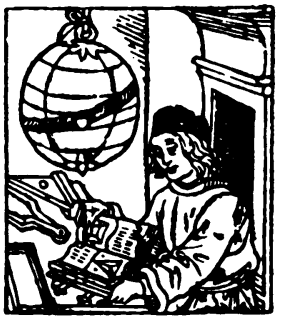

Send for our latest catalogue Jeremy Norman \& Co., Inc. $4+2$ POST STREET

SAN FRANCISCO, C.ALIFORNIA $9+102$ (415) $781-6+02$

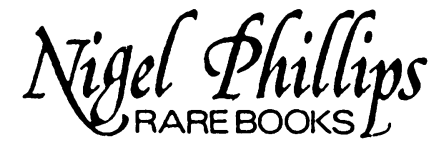

Antiquarian books in the history of medicine and the health sciences.

Please send for my catalogue.

$$
\begin{aligned}
& 26 \text { RADCLIFFE SQUARE } \\
& \text { PUTNEY HILL } \\
& \text { LONDON SW15 6BL } \\
& \text { ENGLAND }
\end{aligned}
$$

Tel: 01-7882664 